\title{
Teeth Will Be Provided: On Signifiers
}

\author{
Richard TARUSKIN \\ University of California, Berkeley \\ 104 Morrison Hall 1200, Berkeley, CA 94720-1200, USA \\ E-mail: taruskin@aol.com
}

(Received: March 2016; accepted: June 2016)

\begin{abstract}
In his autobiography, Goldmark boasted that he had employed four distinct orientalist idioms in his works: one in Sakuntala and three in Die Königin von Saba. Actually, his deployment of orientalist signifiers was a lot more varied and subtle than that. None of them, moreover, was based on actual ethnographic models. All were purely imaginary and conventional - and for that reason legible and effective. This essay surveys and classifies them, analyzes their motivation and effect, and compares them with the practice of contemporaries such as Anton Rubinstein and Camille Saint-Saëns.
\end{abstract}

Keywords: Goldmark, Die Königin von Saba, Orientalism, semiotics

It is an old, old story. I first came across it as an adolescent, browsing in a joke book where it was told about Aimee Semple McPherson, an evangelist who preached to the homeless on the streets of California cities a hundred years ago. ${ }^{1}$ But, I have found, it is a lot older than that. The earliest version I know of, now that I have asked Google, was published in 1885, when our protagonist, Karl Goldmark, might have heard it (but probably did not):

A Presbyterian minister, admonishing freethinking Dr. Russell, the late editor of The Scotsman, warned him to flee from the wrath to come, from the place where there is wailing and gnashing of teeth, and painted the joys of heaven, where ran-

1. Bennett Cerf, Laughing Stock: Over Six-Hundred Jokes and Anecdotes of Uncertain Vintage (New York: Grosset and Dunlap, 1945), 231. 
somed sinners chant a new song unto the lamb. "But what will they do with me?" queried Dr. Russell, "who have neither a voice to sing with, nor teeth to gnash?". "Doctor, doctor", answered the minister solemnly, "the teeth will be provided." 2

Teeth will be provided. The lack of gnashing equipment will not deter us. It can be made to order, and, if needed, will be. Can you see why thoughts of Goldmark led to thoughts of this silly joke? Here's another joke, for a hint. It is a scene from a very funny movie called A Thousand Clowns, which I first saw maybe fifty years ago. Never mind what the movie is about. The part I am recalling here can stand alone. It shows a pair of characters entertaining a third by doing impressions of Thomas Jefferson and Alexander Hamilton. When the third character protests that one cannot do impressions of people whose voices no living person remembers, they tell him "Ha! You missed the funny part."

Once again, we are not deterred by what ought to be a crippling lack. The same goes for artistic representations, particularly representations of the exotic, the thing we have met to consider and discuss. Representing the exotic usually means representing something we know nothing about. The overcoming of this handicap was Goldmark's particular specialty, his main claim to fame, and he knew it. He actually boasted about it in his memoirs, looking back upon his first and most successful opera, Die Königin von Saba, which is set in what we now call the Near or Middle East. "To the musically educated European," he wrote,

oriental music as a whole sounds alike, a matter of well-known differences in scales and characteristic turns of phrase in the minor. It was clear to me, though, that the musical style adapted to picture the grove of the Indian penitents in the Sakuntala [Overture, op. 13, of 1865, the work that made his reputation and established his credentials as an exoticist] could not be used to portray King Solomon's magnificent court; that the music appropriate for either of these scenes would not be appropriate to represent the Arabian Queen of Sheba, or for [her Moorish slave] Astaroth's love call. And still all had to have an oriental character, only each one must be different from the others. ${ }^{3}$

2. "Anecdotes," Our Corner, V, ed. Annie Besant (London: Freethought Publishing Company, 1885), 120.

3. Karl Goldmark, Notes from the Life of a Viennese Composer, trans. Alice Goldmark Brandeis (New York: Albert and Charles Boni, 1927), 210. Translation adjusted by comparison with the original German (Goldmark, Erinnerungen aus meinem Leben (Vienna: Rikola, 1922), 115-116: "Für den musikalisch gebildeten Europäer besteht die orientalische Musik ohne Unterschied einheitlich und in den bekannten Skalendifferenzen und Moll-Melismen. Mir wurde es jedoch klar, daß der Stil des indischen Büßerhaines in der Sakuntala nicht der des prachtliebenden Hofes König Salomons und dieser nicht der der arabischen Königin von Saba und der Lockruf der Astarot sein könne. Und doch sollen alle orientalisches, das heißt verschieden orientalisches Gepräge haben. Dazu gesellte sich noch eine ganz besondere Schwierigkeit: daß die auch orientalisch gefärbten Tempelgesänge für den europäisch gebildeten Hörer weihevollen, religiösen Eindruck machen sollten, ohne den protestantischen Choral oder katholische Marienlieder hiezu benützen zu können. Ich war nie im Orient, aber die Intuition half mir auch darüber hinweg." 
Goldmark distinguishes four "oriental" idioms: the Indian, the Israelite, the Arabian and the Moorish, of which the last three were to be employed and differentiated in his opera. But that was not all. "There was another very special difficulty," he wrote (and it was one that several other composers had faced before him):

\begin{abstract}
I wanted the temple hymns with their oriental coloring nevertheless to express a sense of consecration and religious feeling to people familiar only with European music. The problem was to accomplish this without making use of the Protestant chorale or any of the Catholic hymns to the Virgin.
\end{abstract}

So now we have four contending orientalist idioms in the opera: Moorish, Arabian, and two varieties of Hebrew - one for the court and another for the temple. And then the boast: "I had never been in the Orient," Goldmark informs us, "but intuition helped me even over this lack."

What, though, would it have availed the composer to have visited the Orient? And was it intuition that provided him, so to speak, with teeth? Die Königin von Saba is most accurately described as an opera with a Biblical - that is to say, ancient-world - setting. The sounds of that world, oriental or occidental, are no longer available for mimicry. Thus to imitate the music of the ancient Hebrews or Moors is exactly like imitating the speech of Alexander Hamilton or Thomas Jefferson. Authenticity, if that means resemblance to an actual original, is not even an option - nor would it even be desirable, if no one could recognize it. It cannot reasonably be sought. All one can strive for is verisimilitude - not truth, but (to borrow a word from the American fake-news comedian Stephen Colbert) "truthiness." Colbert coined that word to mock the deceptions practiced by American politicians, who tell voters what they believe the voters want to believe, and which will therefore have in the voters' ears a ring of truth even if, as is usually the case, the ring is false. To be satisfied with, or persuaded by, the ring is to confuse truth with truthiness, verisimilitude with authenticity. And we do it all the time. What sort of ring of truth did Goldmark seek; where did he look for it; and what do his solutions to these self-imposed problems tell us about his and his audience's cultural assumptions? These are the questions I will pursue.

\title{
1.
}

Operas or oratorios with an ancient-world setting were common a century or two before Goldmark's time. Opera seria usually dramatized subjects from ancient Greek, Roman or Egyptian history when it was not drawing on ancient myths, and oratorios were almost always dramatizations of stories from the Bible or the Apocrypha. Stylistic verisimilitude of the kind that Goldmark set it as his task to 
achieve was of no concern to the composers of the seventeenth or eighteenth centuries. The famous Entry of the Queen of Sheba from Handel's oratorio Solomon does not sound the least bit Arabian, and no one would have wished it to. That was not where Handel's audience expected verisimilitude or where Handel would have thought to provide it. The verisimilitude that was sought in such works was verisimilitude in the portrayal of feeling, which was assumed to be a timeless constant, universal human nature.

The assumption that feelings were universal of course remained in effect in nineteenth-century opera, so that a composer like Goldmark had to strive for fidelity to two standards of truthiness at once, and therefore had to apply what is sometimes called double-coding. Marks of local color when applied to characters, so that they become marks of ethnicity, inflected a traditional repertoire of affective portraiture. Difference thus inflected sameness in a calculus infinitely more supple and shaded than Goldmark's fourfold enumeration implied. His solutions came not from intuition, as I do not think I need to convince anyone here, but from well-honed technique. Observing his mind at work on this problem has certainly enhanced my appreciation of his stature as a musician, which raises another interesting question about him: why has his music disappeared from the concert and operatic repertories, outside of ceremonial revivals like the one we are enacting now.

When I was starting life as a concertgoer, radio listener, and record collector, there were at least two Goldmark items that were firmly in current repertory even in America: the Rustic Wedding Symphony and the Violin Concerto. No longer. Goldmark is now a rarity in live performance where I come from. During the first two decades of its existence, however, Die Königin von Saba was not only enthusiastically received, but also widely assumed to be a classic in the making, an opera whose popularity would never wane. In 1897, twenty-two years after its Vienna première, the opera reached its hundredth performance both in Vienna and in Budapest. By the end of the nineteenth century, three years later, it had been performed on the main German-language stages (Hamburg, Prague, Berlin), as well as in Turin, St. Petersburg, Rotterdam, New York, Madrid, Boston, Warsaw, Riga, Zürich, Antwerp, Buenos Aires, Amsterdam, and Zagreb, in that order. It is listed and described (along with Goldmark's Merlin) in the trusty handbook, The Standard Operas (Chicago, 1899), on which I have long relied for evidence of what deserved to be called "standard" at that time. ${ }^{4}$ But between 1900 and 1940, Alfred Loewenberg's Annals of Opera, the source of most of the

4. George P. Upton, The Standard Operas: Their Plots, Their Music, and Their Composers (Chicago: A. C. McClurg and Company, 1899), 117-120. In the preface to his discussion of the opera, the author says of Goldmark, "Four of his compositions during the past fifteen years, the "Sakuntala" overture, the operas The Queen of Sheba and Merlin, and "Die ländliche Hochzeit" (The Country Wedding) symphony have made a permanent reputation for him" (p. 116). 
foregoing factoids, records only five productions to compare with the eighteen stagings, on three continents and in only half the time, which I have just enumerated. ${ }^{5}$

When the ten-year-old opera first reached the New World, at the Metropolitan Opera in New York on 2 December 1885, it was greeted with a shower of superlatives from two very distinguished critics. Henry Krehbiel, the music editor of the New York Herald, put it in the most majestic, or at least best-rewarded, possible company, writing that "in The Queen of Sheba are combined more of the elements which go to make up a successful opera than in any new work that has been seen since Verdi enriched the stage with Aida, unless it be Carmen, which, for many reasons, must be given a unique position among latter-day creations."6 Even allowing for the possibly barbed use of the word "successful," and even if Krehbiel may have been selecting only analogously orientalizing operas for comparison, it is obvious that he foresaw for Goldmark's opera a future comparable to those of Verdi's and Bizet's. The next season, when Die Königin von Saba was chosen for the opening night gala at the Met, Krehbiel's rival W. J. Henderson of the New York Times wrote that it was certain to be "the artistic and social event of the Winter."

Since the Metropolitan was opened to the public [three years earlier], no audience of like brilliancy has been gathered within its limits. And since opera was first given in the United States, no representation more commendable in point of symmetry and none that could be at all compared with yesterday's in respect of the perfection of the orchestra performance and the completeness and splendor of the mise en scène has ever been beheld in the New World. It is simple justice to place these facts on record at the outset of a reference to last night's rendering of The Queen of Sheba, for the magnificence of the entertainment and the quality and numbers of the assemblage that witnessed it were the only themes that can be dwelt upon without repeating much that has been already written in this place concerning Goldmark's masterpiece and its chief interpreters in this city.

And yet, less than twenty years later, the opera had been nearly forgotten. Revived in 1905 for the first time since 1890, it moved the anonymous New York Times reviewer to ruminate on its disappointing fate. "The Queen of Sheba," he allowed,

5. Alfred Loewenberg, Annals of Opera 1597-1940 (Totowa, NJ: Rowman and Littlefield, 1978), 1045-1046. 6. http://archives.metoperafamily.org/archives/scripts/cgiip.exe/WService=BibSpeed/fullcit.w?xCID=4300 (accessed 11/25/15).

7. http://archives.metoperafamily.org/archives/scripts/cgiip.exe/WService=BibSpeed/fullcit.w?xCID=5250 (accessed 11/25/15). 
is still a living item in the repertories of the greater German opera houses. But in New York the fifteen years that have gone by since it was produced here have seen some marked changes in the kind of taste that Goldmark's opera appeals to. Its music now makes less of an appeal to ears that have become more attuned to the sources whence Goldmark derived much of his inspiration, and perhaps in certain ways more exacting. And while splendor of theatrical effect will always make its way, and always has, there is such a thing as piling Pelion upon Ossa and wearying by the very superfluity of gorgeousness. ${ }^{8}$

That last idiom, no longer current, means heaping one mountain atop another - too much of a good thing, or else compounding difficulties. Even in the midst of his rapturous review of the Met première, Henry Krehbiel gave an inkling of what there may have been too much of, and it is the very thing that brings us together today. "Herr Goldmark's music is highly spiced," he wrote. "He is plainly an eclectic, whose first aim was to give the drama an investiture which should be in keeping with its character, externally and internally." That much might have been said of Aida or Carmen, thus by extension of Verdi or Bizet. But then Krehbiel added, "many other composers before him have made use of Oriental cadences and rhythms, but to none have they seemed to come so like native language as to Goldmark." What was said ostensibly in praise in 1885 nevertheless broached one of the big issues to which David Brodbeck has devoted a recent book, and which not even the composer's friends (e.g., Brahms) could keep entirely at bay, the charge of being fremdartig, the German equivalent of what we now mean when we capitalize the word Other.

The charge of eclecticism - the chameleon assumption of many styles rather than the assiduous cultivation of a unique and instantly recognizable voice - was one of the charges Wagner levelled at Jews in his notorious tract of 1850, which he had owned to having written six years before Die Königin von Saba had its première. Mimicry, even if done with verve and virtuosity, and even if done so persuasively as to create the aura of authenticity, nevertheless transgresses against another sense, perhaps the most exigent one, of the word "authenticity". For eclecticism impedes the impression of personal authenticity, also known as integrity, which was more and more insisted upon as romanticism moved into its late, late phase known as modernism. Yet that transgressive eclecticism was precisely the virtue that Goldmark so assertively claimed for himself in the boastful passage I have quoted from his memoirs about the oriental idiom - or rather idioms - he contrived for his opera. He did not use the tainted word; he would no doubt have preferred to speak of versatility rather than eclecticism. But versatility is also an 
antonym of integrity, hence of personal authenticity, the overriding sentiment of self. To value versatility over originality transgressed against what was becoming, with a powerful push from Wagner, a sine qua non.

Meanwhile, Wagner was one of the elements that Goldmark's versatility sought to encompass, although the Wagnerian influence shows up less in the music of his opera than in the dramatic action, the plot being one of the teeth the authors of Die Königin von Saba had to provide. The opera's story does not come from the Bible, where the Queen of Sheba (malkat Sh'ba) makes only the briefest of appearances, as recounted twice, in almost identical words, in the tenth chapter of First Book of Kings and ninth chapter of the Second Book of Chronicles. Here is the account from Chronicles in the King James version, slightly abridged:

[1] And when the queen of Sheba heard of the fame of Solomon, she came to prove Solomon with hard questions at Jerusalem, with a very great company, and camels that bare spices, and gold in abundance, and precious stones: and when she was come to Solomon, she communed with him of all that was in her heart.

[2] And Solomon told her all her questions: and there was nothing hid from Solomon which he told her not.

[3] And when the queen of Sheba had seen the wisdom of Solomon, and the house that he had built,

[4] And the meat of his table, and the sitting of his servants, and the attendance of his ministers, and their apparel; his cupbearers also, and their apparel; and his ascent by which he went up into the house of the Lord; there was no more spirit in her.

[5] And she said to the king, It was a true report which I heard in mine own land of thine acts, and of thy wisdom:

[6] Howbeit I believed not their words, until I came, and mine eyes had seen it: and, behold, the one half of the greatness of thy wisdom was not told me: for thou exceedest the fame that I heard.

[7] Happy are thy men, and happy are these thy servants, which stand continually before thee, and hear thy wisdom. [...]

[9] And she gave the king an hundred and twenty talents of gold, and of spices great abundance, and precious stones: neither was there any such spice as the queen of Sheba gave king Solomon. [...]

[12] And king Solomon gave to the queen of Sheba all her desire, whatsoever she asked, beside that which she had brought unto the king. So she turned, and went away to her own land, she and her servants.

Not much of a story here, which if historical is probably just a reference to a trade mission. The Queen is characterized as rich, not beautiful. I have pruned 
away some of the great show of opulence that surrounds her in the Biblical account, but enough remains to suggest what attracted the attention of so many artists and musicians to the Queen's visit. (One of the attractions for musicians was a verse about harps and psalteries which King Solomon had made from the wood of the algum trees the Queen had given him in tribute. $)^{9}$ But there is plenty of room for the imagination, especially when the Bible tells us that "neither was there any such spice as the queen of Sheba gave king Solomon; and king Solomon gave to the queen of Sheba all her desire." It was a snap to associate the Queen of Sheba with the Bride in the Song of Songs, hence with the line best known in St. Jerome's Latin translation, Nigra sum sed formosa ("I am black but comely" according to King James). ${ }^{10}$ Building on this, the national saga of Ethiopia, Kebra Nagast (thought to date from the fourteenth century), traces the country's ruling dynasty to Menelik (i.e. "Son of the wise man" in Amharic), the love-child of Solomon and Sheba.

Handel's Solomon, English to the bone, takes no manly interest in the Queen of Sheba; he is wrapped up in uxorious bliss with his own wife (the Pharaoh's daughter) and in the oratorio's third act, Sheba's, the librettist is too busy "exalt[ing] reason, wisdom, wealth, and cultural ostentation" to spare a thought for sex. ${ }^{11}$ But by Goldmark's time, a "Queen of the South," especially one whose South is located in the East, had to be an embodiment of allure. In his memoir Goldmark attributes his first thought of the opera to a chance remark made by the stage manager of the Vienna Court Opera about a fifteen-year-old pupil of Goldmark's, who had just made her début (presumably in the chorus): "Look at that girl! That face! The very image of the Queen of Sheba!"12 Goldmark immediately sketched a scenario, he tells us, "which contained, in outline, practically all that is now included in the opera." ${ }^{13}$ It is, inevitably, a love triangle, in which the Queen performs the role foreordained by romantic orientalist convention as well as ironclad operatic precedent. Here is Brodbeck's efficient summary of the action:

The story is set into motion when the queen - depicted as an exotic femme fatale - seduces the courtier Assad, who has been sent by Solomon to meet her in the desert and escort her into Jerusalem. The queen privately reveals her attraction to the young man, but in public she denies even knowing him. Driven to frenzy, Assad abandons his betrothed, Sulamith, daughter of the High Priest, at their wedding in the Temple and publicly declares the queen his

9. I Kings 10:12.

10. The Song of Solomon 1:5.

11. Percy M. Young, Handel (London: Dent, 1947), quoted in Paul Henry Lang, George Frideric Handel (New York: W. W. Norton, 1966), 465.

12. Goldmark, Notes, 205. "Das Mädl! Das Gesicht! Die reine Königin von Saba!” Goldmark, Erinnerungen, 114 .

13. Goldmark, Notes, 206. 
goddess. At first condemned to death for his blasphemy, Assad is eventually banished instead to the wilderness to work out his salvation by defeating the powers of evil. There, in the end, he rejects the vile queen's entreaties and dies in the faithful Sulamith's arms during a ferocious desert storm. ${ }^{14}$

Unlike her close contemporaries Carmen and Delilah, who were already femmes fatales in their literary sources, the Queen of Sheba had to be transformed into one. Knowledgeable observers had no trouble deducing the path she had traveled to get where Goldmark needed her to be. Krehbiel, for one, assured his readers that Die Königin von Saba "is not a biblical opera even in the sense that Mehul's Joseph or Rubinstein's Maccabees and Sulamith are biblical". "The local color of the opera has been borrowed from the old story," he went on, ${ }^{15}$ but "the dramatic motive comes plainly from Wagner's Tannhäuser, as will be evident on a moment's reflection." Only the opera's local color comes from the Bible, he affirmed.

Thus alerted, we can easily map Goldmark's characters onto Wagner's: Tannhäuser = Assad; Sulamith = Elisabeth; Saba = Venus. Krehbiel tries to extend the triangle into a quadrilateral by paralleling Solomon with Wagner's Wolfram, but Henderson, the reviewer for the rival newspaper, seems closer to the mark when he observes that "Solomon performs the baritonal functions of a King of Brabant", thus adding Lohengrin to the Wagnerian mix. And we can add Tristan und Isolde as well, for there is an obvious recollection in the second act of Brangäne's Tagelied, when the Watchman of the Temple calls out, at the climax of the love scene between the illicit paramours, "Der Tag ersteht! Söhne Israels zum Morgengebet!" - whereupon we realize that Assad, like Tristan, was the King's emissary to escort a royal visitor from abroad with whom there springs up, as between Tristan and Isolde, a mutual, fatally destructive passion; and to complete the parallel, Assad dies at the end of the opera, like Tristan, as a castaway in the wilderness, and in the arms of his beloved (though not the beloved with whom he sang his second-act duet).

Now, just as its plot had been concocted from the shards of remembered operatic models, so were the opera's signifiers that defined its various oriental strains. All were taken off the rack, the products neither of intuition, as Goldmark claimed, nor of his own ineluctable Fremdartigkeit, as hostile critics alleged, but rather the fruit of professional knowhow, in which he took an eminently justifiable pride. Brodbeck pinpoints the distinction with precision, recommending that we conceive of Die Königin von Saba "not as a Jewish national opera or even a

14. David Brodbeck, Defining Deutschtum: Political Ideology, German Identity, and Music-Critical Discourse in Liberal Vienna (New York: Oxford University Press, 2014), 84.

15. http://archives.metoperafamily.org/archives/scripts/cgiip.exe/WService=BibSpeed/fullcit.w?x$\mathrm{CID}=4300$ 
'Jewish-Oriental' one, but as an out-and-out Orientalist opera." The only part of that definition that I would wish to modify is the squeamish "out-and-out." To call Goldmark an Orientalist in this connection need not imply that he wickedly approved of the imperialist exploitation of the backward peoples of the East (although like any affluent European, he can all too easily be shown to have benefited from it). The point relevant to this discussion is that, as he persistently maintained in rebuttal to those who sought to "other" him, he identified with European, and more particularly German, culture, and saw his work as belonging

in its entire structure to German art, [...] just as the composer, living among Germans (in Vienna) since his childhood, owes his entire artistic Bildung to German art - Beethoven and Bach were his teachers. The "Fremde" in the work is nothing other than the strong representation of a musical characteristic that is appropriate to the subject matter. ${ }^{16}$

It is that "representation," consisting of Goldmark's Orientalist signifiers, to which we are now ready to turn.

\section{2.}

There are a great many of them, and if they do not sort quite as neatly as Goldmark implied into four discrete boxes, they are nevertheless quite effectively selected for the purposes they were designed to serve. In no case had Goldmark been their designer, but he chose them astutely and adapted them inventively.

The most proximate precedent, as Brodbeck has recognized, was set by Anton Rubinstein, who by 1875 had composed two of his so-called Biblical operas, as well as the earlier, more generically orientalist Feramors, based, like an opera Félicien David was composing at the same time, on Thomas Moore's oriental romance Lalla Rookh. (David's opera beat Rubinstein's to the stage by a year, which is the reason why David's is named after Moore's title character, while Rubinstein had to content himself with the name of her lover.) These operas, plus David's prototypical "symphonic ode" Le Désert (1844), established the orientalist vocabulary on which Goldmark drew. We know he knew them all, not only because musicians of the late nineteenth century can be presumed to have known them, particularly in the German-speaking countries where Rubinstein's operas were major repertory pieces, but also because Goldmark actually reviewed David's compositions for a Vienna newspaper during an early stint as a paid music jour-

16. Goldmark, "Gedanken über Form und Stil (Eine Abwehr)" [Thoughts on form and style: A Defense], Neue Freie Presse (4 June 1911); quoted in Brodbeck, Defining Deutschtum, 306. 
nalist, ${ }^{17}$ and because he and Rubinstein, to whom he devoted an entire short chapter in his memoirs, were on intimate terms as early as $1860 .^{18}$ They even shared a librettist, the Viennese Jewish poet Salomon Hermann Mosenthal, who at the time of his collaboration with Goldmark on Die Königin von Saba was fresh from work on Die Maccabäer, Rubinstein's most successful opera.

In Die Maccabäer, and in the earlier Der Thurm zu Babel (first performed in 1870), Rubinstein faced the problem Goldmark described in his memoirs, namely that of differentiating among diverse oriental strains and in particular, differentiating the Israelites' religious music, which Europeans regarded as an early layer of their own religious and musical tradition, from truly fremdartig orientalist styles without making the Israelites sound Christian. It was a problem faced previously by the Russian composer Alexander Serov, whose first opera, Judith, performed the same year as Rubinstein's Feramors (1863), pitted Israelites against Assyrians. Serov had reserved all the oriental markers for the latter, the Assyrians, leaving the Israelite music unmarked, so that it fell into what in his memoirs Goldmark called the trap of reminding listeners "of the Protestant chorale or [...] Catholic hymns to the Virgin."

It was not a matter of actual imitating the music of the Protestant or Catholic liturgies, only of permitting the Israelites to use the default style of contemporary European music, which in Serov's case (as in Rubinstein's or Goldmark's) was a rather old-fashioned German style, vintage 1840 or so, redolent of Mendelssohn and Schumann. So the omission of signifiers was itself a signifier; and that is why it is better in this context to speak not of signification but rather, using the vocabulary of linguists, of marking. Serov had left the Israelite music unmarked, which, given the expectations of his audience, amounted to marking it Christian. That is why Serov's Assyrian music was much preferred to his Israelite idiom. Rubinstein learned from Serov's negative example to differentiate orientalist markers and distribute them among the various groups he needed to characterize.

Especially instructive as an example was Der Thurm zu Babel, an opera that, as its plot actually dictated, was all about the differentiation of idioms. At its center are three monumental choruses to mark off from one another the descendants of Noah's three sons, Sem, Ham and Japhet, as they are rent asunder into three nations with mutually unintelligible tongues. The children of Sem - that is, the "Semites" - are given the most obvious or predictable all-purpose orientalist marker, the augmented second (Example 1). They sing in unison, as do the sons of Ham, whose melody in C-sharp minor, devoid of leading tones, has Phrygian cadences instead, accompanied throughout by a pedal of drone fifths, giving way toward the end to a snaking chromatic bass (Example 2). The Japhetic chorus,

17. Brodbeck, Defining Deutschtum, 72.

18. Goldmark, Notes, 123-128. 
meanwhile, alludes to a locus classicus, the "Turkish Dance" in the fourth act of Glinka's Ruslan and Lyudmila (compare Examples $3 a$ and $3 b$ ).

One can find many similar devices in Die Königin von Saba, likewise differentiated and distributed, and critics noticed and reported them at the time of its first performances just as we do now. Their interpretation, however, followed a curious trajectory. There were always those who attributed the markers, just as we now do (or, as I am suggesting, should do) to what Brodbeck calls "an exoticist strategic choice on the composer's part." 19 But there were also those who, in Goldmark's own words, tended insultingly to attribute his orientalisms not to his Stück but to his Gemüt, or as the translator of his memoirs put it, "they were attacking my

Example 1 Rubinstein, Tower of Babel (New York: G. Schirmer, 1883), "Chorus of the Sons of Shem"

$1^{\text {st }}$ PICTURE.

Allegro non troppo.

Chorus of the Sous of Shem.
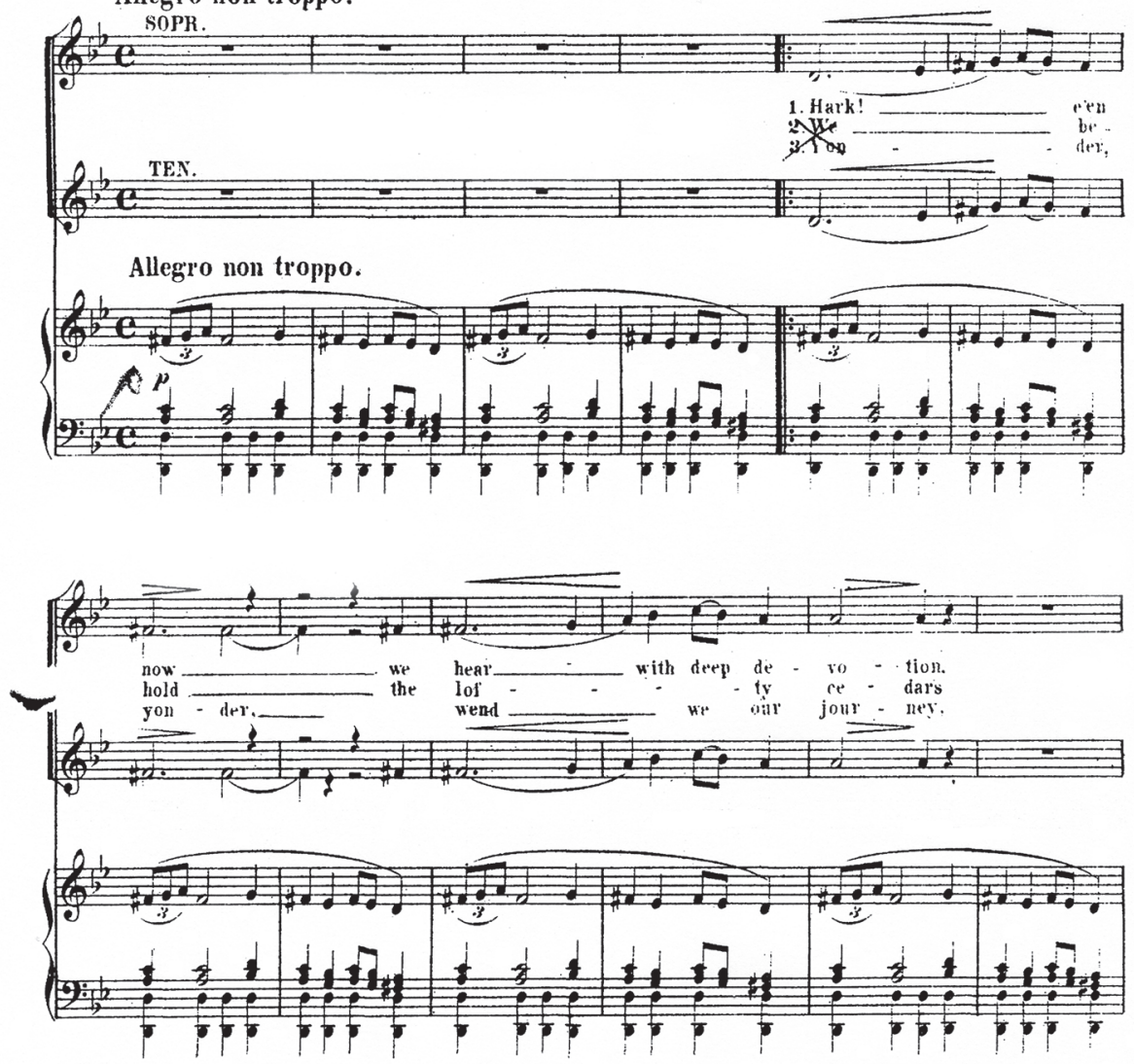

19. Brodbeck, Defining Deutschtum, 75. 
Example 2 Rubinstein, Tower of Babel, "Chorus of the Sons of Ham"

24 PICTURE.

Chorus of ihe Sons of Ham.
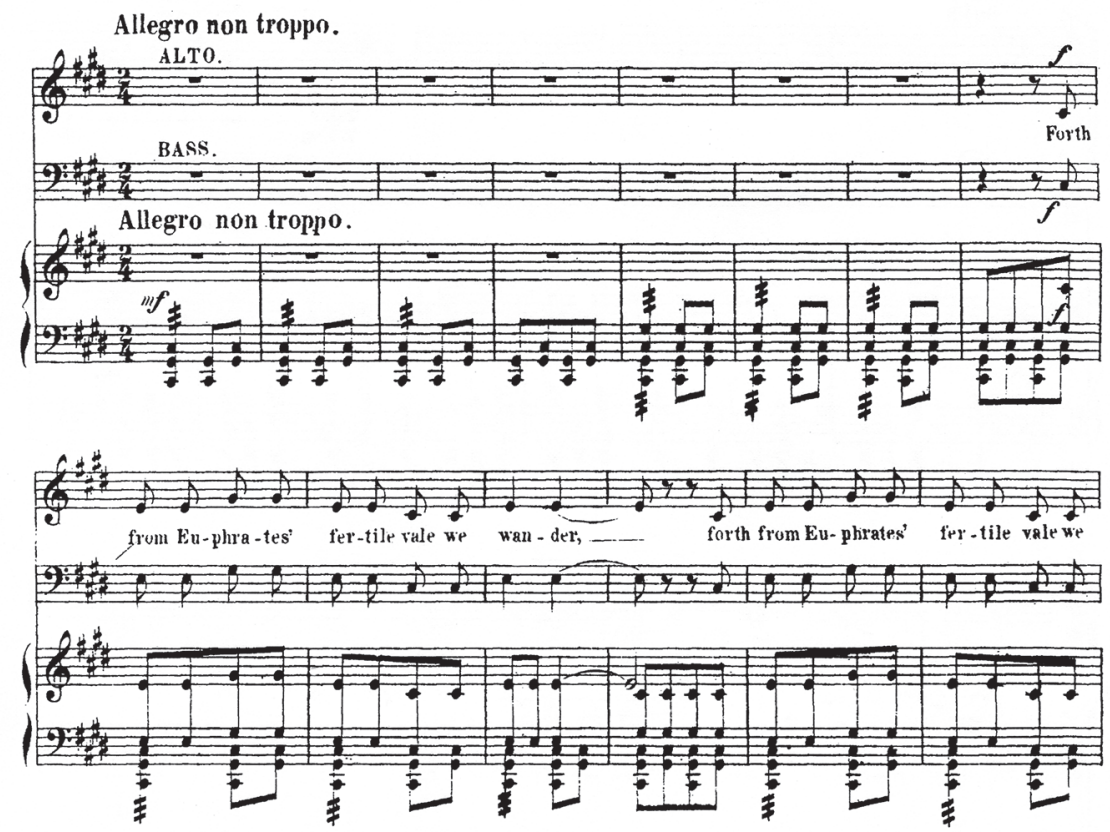

temperament rather than my composition," 20 aiming their observations not ad rem but ad hominem. The same critic, in fact, could at various times argue either way.

Hanslick was one. In 1884 he observed that "to the modern composer, the ethnographically sharp differences among Indian (exemplified by Meyerbeer's L'Africaine or Delibes's Lakmé in addition to Goldmark's Sakuntala), Persian (exemplified by Feramors or Lalla Roukh), Egyptian (Aida), Hebraic (Die Königin or Die Maccabäer) must in any case nearly dissolve into a general idea: oriental music" 21 - by which he meant not that they were all the same or interchangeable but that their representation and differentiation were arbitrarily imagined, so that, as Brodbeck puts it, the markers "relate much more closely to one another than they do to any particular ethnic musical practice." 22 And yet the same Hanslick, writing two years later, backslid into an appalling essentialism. Reviewing the latest Goldmark opera, Merlin, he remarked with approval that it is free of the

20. Goldmark, Notes, 175.

21. Eduard Hanslick, "Hofopernteater," Neue Freie Presse (7 October 1884), quoted in Brodbeck, Defining Deutschtum, 215.

22. Brodbeck, Defining Deutschtum, 306. 
Example 3a Rubinstein, Tower of Babel, "Chorus of the Sons of Japhet"

3d PICTURE.

Moderato con moto.

Chorus of the Sons of Japhet.

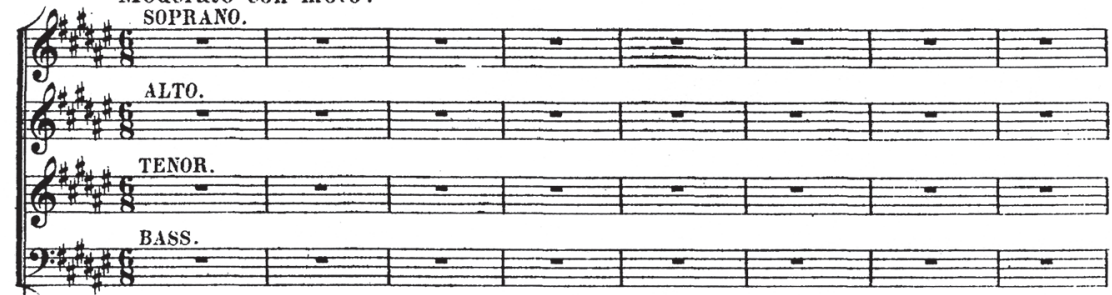

Moderato con moto.

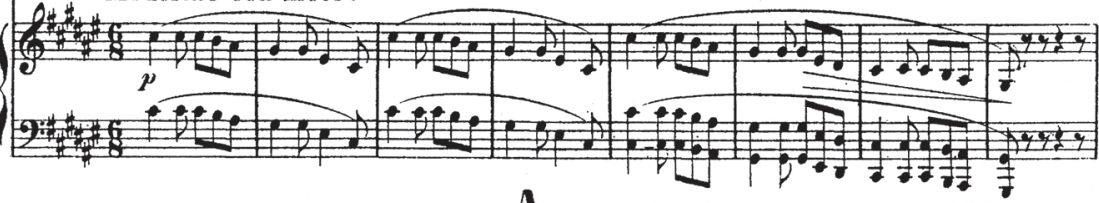

A

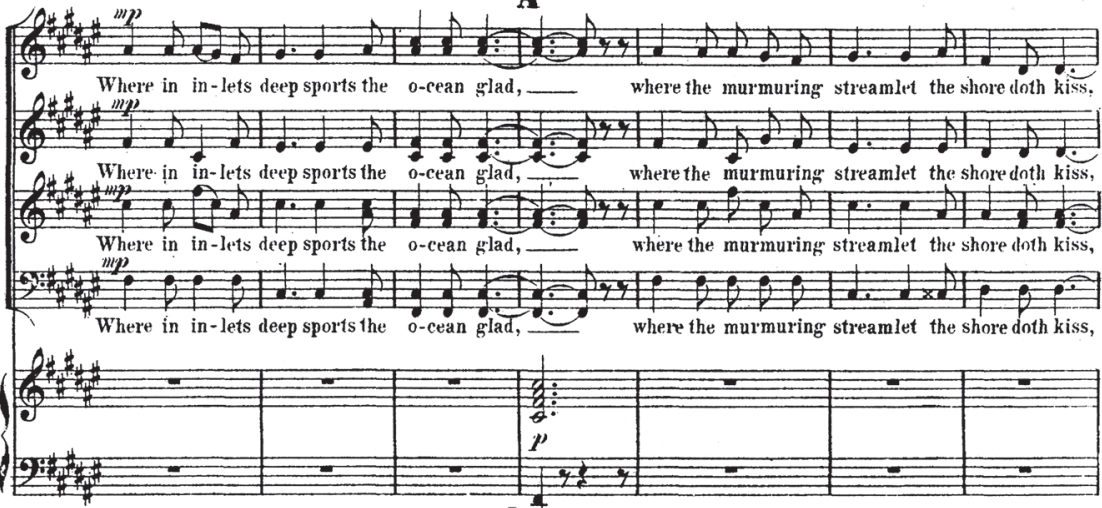

A

EXAmPLe 3в Glinka, Ruslan and Lyudmila, Act IV, Turkish dance

a) Typenkrî. Türkisch.

Allegretto quasi Andante, m.M. $d=60$.

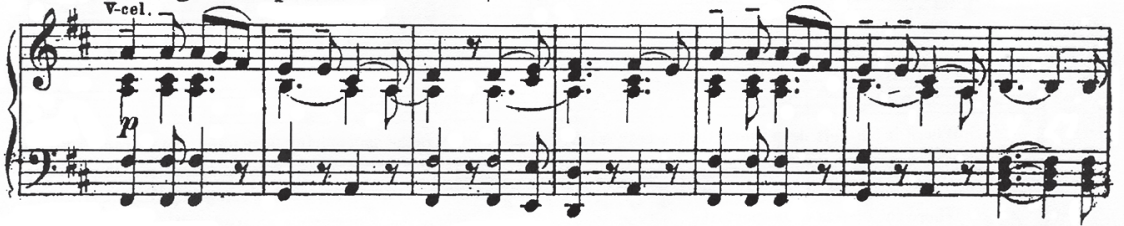


"Jewish-Oriental melodies, whose sickly moaning spoiled for us the undeniable beauties" of Die Königin von Saba, and then added:

\begin{abstract}
The subject matter [of Die Königin] certainly justified the Jewish local color in the music, but did not make it any more pleasing. Will Die Königin von Saba, precisely because of this striking national character, be judged more original, more "Goldmarkian" than Merlin? That may be the case and would not exactly be unfounded. The Oriental, with its passion and colorful display, but also with its unrest, intensity, and exalted solemnity, does not lie merely within the subject matter of Die Königin von Saba, but within our composer himself, who grew up under a doubly Oriental influence, the Jewish and the Hungarian. ${ }^{23}$
\end{abstract}

Take that, residents of Budapest! Goldmark's very ability to produce Merlin after writing Die Königin should have been enough to refute these silly surmises, had they been actual surmises. But rather than surmises they seem to have been defensive strategies, attributable to the same squeamishness in a German-speaking Jewish immigrant from the outlying provinces to Vienna - Hanslick's identity as well as Goldmark's - that affected the composer's treatment of his orientalist markers, albeit in a manner exactly opposite to what Hanslick was proposing. I turn with relief from Hanslick's obtuse ruminations to the most intelligent contemporary take on operatic orientalism, that of the Russian critic with the French and German names, Gherman [Hermann] Avgustovich Larosh [Laroche], who, reviewing Rubinstein's Die Thurm zu Babel, asked rhetorically, "In what does Alexander Serov's masterly characterization of the extinct Assyrians in his opera Judith consist, or Anton Rubinstein's of the ancient Semites in his "sacred opera" The Tower of Babel?" and answered, "Obviously, in one thing only: the composers have successfully reproduced our subjective idea of the Assyrians and the Semites." 24

This gets everything right. It places the emphasis not on the composer's input, but on the audience's takeaway, or rather the composer's strategic calculation (as Brodbeck would say) of the audience's likely perception, which enables the critic to see that teeth were being provided, and Alexander Hamilton and Thomas Jefferson were being successfully, that is, "truthily" impersonated. 216

23. Hanslick, "Merlin,” Neue Freie Presse (21 November 1886), quoted in Brodbeck, Defining Deutschtum,

24. Hermann Laroche (German Larosh), “DerThurm zu Babel' Rubinshteyna,” in Larosh, Muzikkal'no-kriticheskiye stat'i (St. Petersburg: Bessel, 1894), 117. 
3.

So let us take a closer look at that impersonation, that novel deployment of stereotypes, to put it in terms of an apparent oxymoron that I will try eventually to redeem. For I believe that Goldmark's treatment of his orientalist markers is subtler and more canny than any of those invoked thus far, and - it follows - more interesting. This applies especially to the most hackneyed signifier of them all, the augmented second.

Augmented seconds are remarkably scarce in Die Königin von Saba, compared with Rubinstein's operas, or with the exactly contemporaneous Samson et Dalila by Saint-Saëns. Everybody remembers the famous Bacchanale from Samson et

Example 4 Saint-Saëns, Samson et Dalila, Act III, Bacchanale, middle section
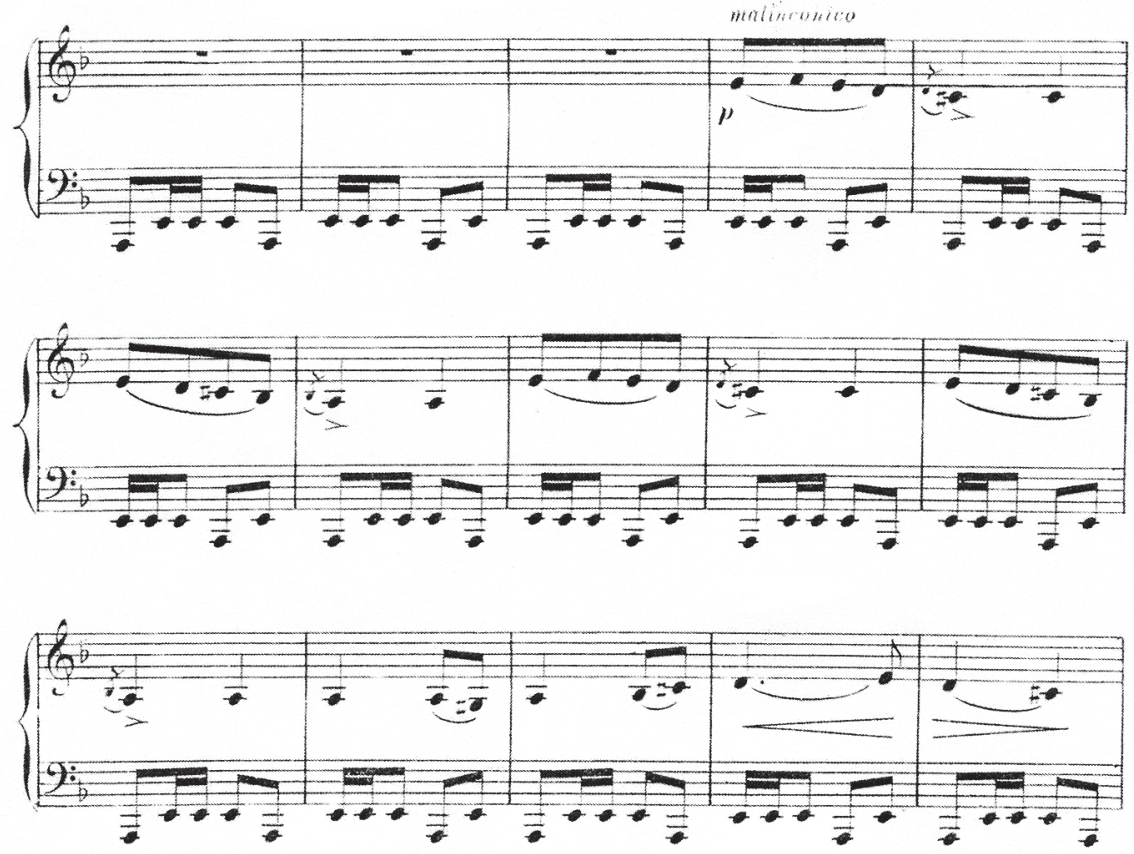

Dalila (Example 4). Die Königin von Saba has one, too. It is the culmination of the ballet at the beginning of Act III, which takes place not among Saint-Saëns's Philistines but at King Solomon's court. As orgies go, it is pretty restrained, the way Goldmark's orientalism always tends to be compared with its French or Russian counterparts (Example 5). 
Example 5 Königin von Saba (Bremen: Schweers \& Haake, [1881]), Act III, Bacchanale

Bachanale.

Mässig schnell. $d=160$.

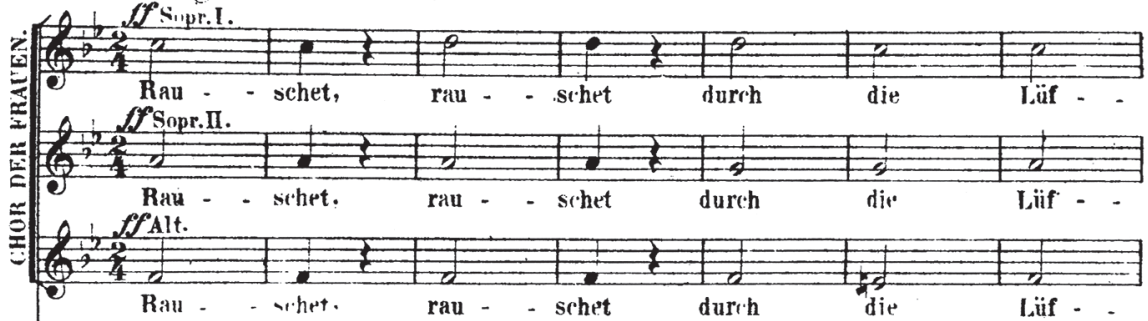

Mässig srhuell. $\bullet=160$.
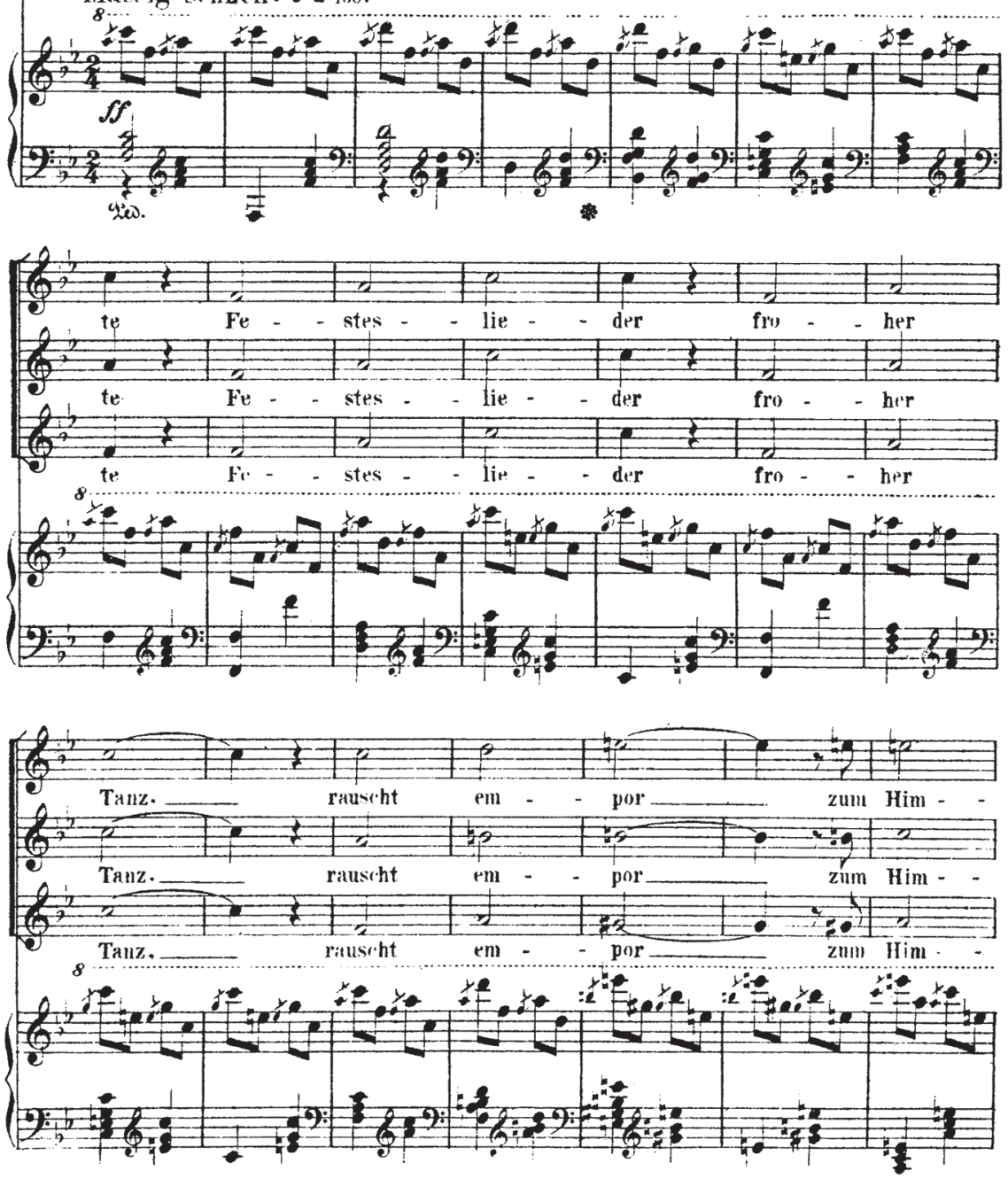
Partly, as David Brodbeck would (I suspect) confirm, it was a matter of Deutschtum oblige. Among the ways German art flaunted its superiority was in its civilized, decorous deportment, with which Goldmark strongly identified. The other cause of that restraint was surely the qualms Goldmark felt on account of his Jewishness. We have already encountered Henry Krehbiel's assumption that Goldmark was speaking his "native language" in Die Königin, and we have seen Hanslick, another assimilated and precariously successful Austrian Jew, react with squeamishness to the opera's Jewish palette - a squeamishness, I think it is safe to assume, that was not unrelated to the composer's.

The essentializing process can work in the other direction as well. Saint-Saëns was often suspected of being Jewish. During the Dreyfus years the rumor went around that his actual surname was Kahn (i.e., that he was a member of the big banking family of that name) and the Nazis banned his music. ${ }^{25}$ And as usual, whatever the Nazis banned, Jewish chauvinists would claim on the same evidence - evidence furnished, in the case of Saint-Saëns, by nothing more than the augmented seconds in Samson et Dalila. Here is Gdal Saleski, a Ukrainian-born cellist and amateur writer on music, whose well-known biographical dictionary, Famous Musicians of Jewish Origin (first published as Famous Musicians of a Wandering Race) had this to say about Saint-Saëns, who

embodies one of the many aspects of the French temperament - that in which the mind and intelligence supplant sentiment and emotion, as in the case of a Voltaire, of a Rameau, - that is, of course, as long as Saint-Saëns remained the patriotic Frenchman, a patriot who could attack Wagner for no better reason than that he was a German. But as soon as he dug down to the roots of his own being and for once forgot that he was above all a Frenchman, he succeeded in composing his one immortal work, written on a biblical theme, in which he freely employed the Hebrew scale. In his "Samson et Dalila," not only one of the master's best operas (perhaps the very best), but one of the finest dramatic works produced by any French composer during the last fifty years, SaintSaëns compelled the admiration of musicians as well as of the general public, possibly for the reason that when he wrote it he did not attempt to please either, but was content to follow ancestral inspiration without arrière pensées [sic] of any sort. ${ }^{26}$

And here is Saleski on Goldmark, who despite "the influence of Wagner's theories,"

25. Michael Kater, The Twisted Muse: Musicians and Their Music in the Third Reich (New York: Oxford University Press, 1997), 85.

26. Gdal Saleski, Famous Musicians of Jewish Origin (New York: Bloch Publishing Company, 1949), 127. 
nevertheless shows much originality and individuality. He [...] was much attracted by biblical material, and he brought to it all the passion of his Viennese temperament and all his love for the history of the Jewish nation. ${ }^{27}$

Show me your blood and I will show you the kind of music you will write; show me your music, and I will show you what kind of blood you have. And if the music and the blood do not match up, you lack authenticity. Obviously Goldmark wanted none of that. So no augmented seconds in his Bacchanale. Not that the music lacks its share of markers. It abounds in chromatic scales, including a descending one in the bass like Rubinstein's. It has syncopated rhythms galore. It has ostinatos aplenty. But (trust me) there is no "Hebrew scale." Owing to their scarcity, then, Goldmark's augmented seconds are especially telling when they do occur.

What do these telling seconds tell us? One of their rare appearances occurs near the end of the triumphal march that accompanies the entry of the title character in Act I. Like its counterpart in Aida, Goldmark's march has various contrasting strains that succeed one another as various groups of marchers pass in

EXAmPle 6A Königin von Saba, Act I, Einzugsmarsch, "Soldaten ziehen auf"

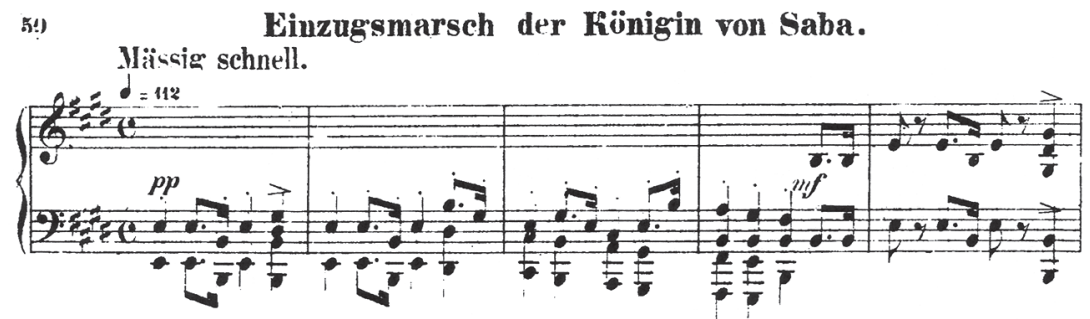

EXAmple 6в Königin von Saba, Einzugsmarsch, "Aus den Seitenhallen ziehen Frauen u. Jungfrauen, von Sclavinnen begleitet"
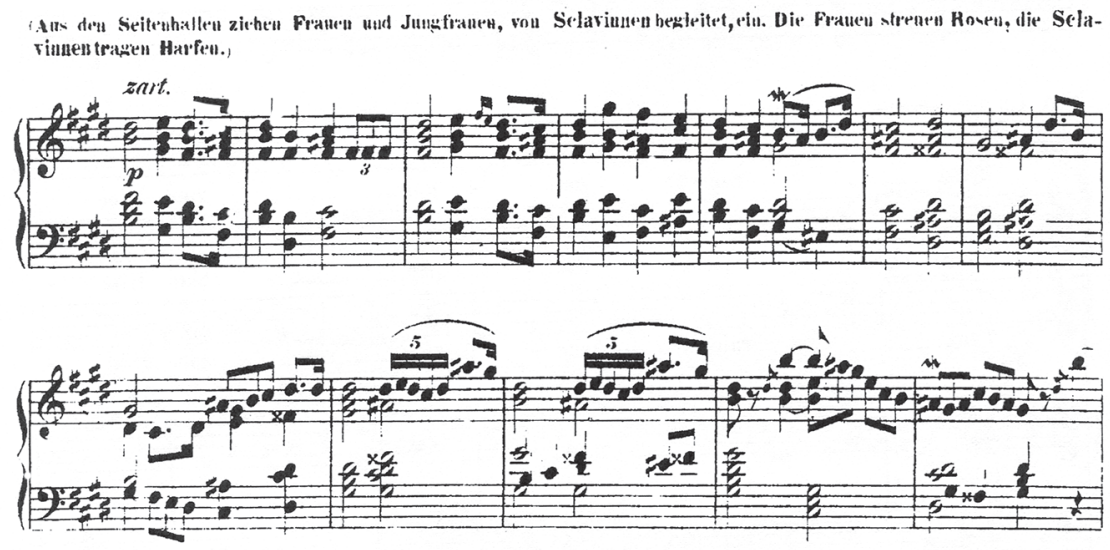

27. Ibid., 69. 
review. First to appear are soldiers, presumably Solomon's (Example 6a), followed by women and maidens, accompanied by Solomon's female slaves, strewing roses (Example 6b). Things get a bit wilder when the Queen's retinue makes its entrance. (They are from Arabia, after all, which makes them fremdartig.) First to appear are her male slaves, both white and black, bearing vessels filled with gold dust, pearls, jewels and spices - and here we notice drone fifths, like Rubinstein's in the Hamitic chorus from Der Thurm zu Babel (Example 6c).

And now, as Sigmund Freud would say, we get to where the body's buried, when the female slaves appear, both black and white, and with them augmented seconds galore. After a brief reprise of the music associated with the male slaves, the Queen makes her climactic appearance, borne aloft on a palanquin or covered litter, accompanied by her main personal slave Astaroth, who is designated "eine Mohrin" in the cast of characters (Example 6d). Nota bene: augmented seconds make their appearance upon the arrival of dark skin and female gender.

This association will hold through the opera, including its most spectacular Orientalizing moment. But before getting to that, one slight apparent exception must be acknowledged, namely the first theme in the Prelude to the First Act. But for a couple of solemn introductory phrases, these are the very first sounds the audience hears (Example 7a). Our marker-seeking ears prick up at this, of course; but as first heard in Example 7a the augmented second is a floating signifier, as yet unattached to a referent and therefore not yet, strictly speaking, a signifier at all, except insofar as it identifies the whole opera as "oriental" - something the title has already done. It is a familiar poser: at what point does a leitmotif actually become a leitmotif. The short answer, obviously, is "at the first repetition"; so we only learn what the music in Example 7a is supposed to signify at the beginning of the fifth scene in Act II, the aborted wedding of Assad and Sulamith, when the priests sing to it the beginning of the liturgy, "Danket dem Herrn, denn er ist freundlich! Ewig währt seine Güte!" (Example 7b).

So here an augmented second (as well as a diminished fourth) is being associated with the Israelites: with "us," you might say, if we are speaking Biblically, not

EXAMPLE 6c Königin von Saba, Einzugsmarsch, "Sclaven und Sclavinnen, Weisse und Mohren"

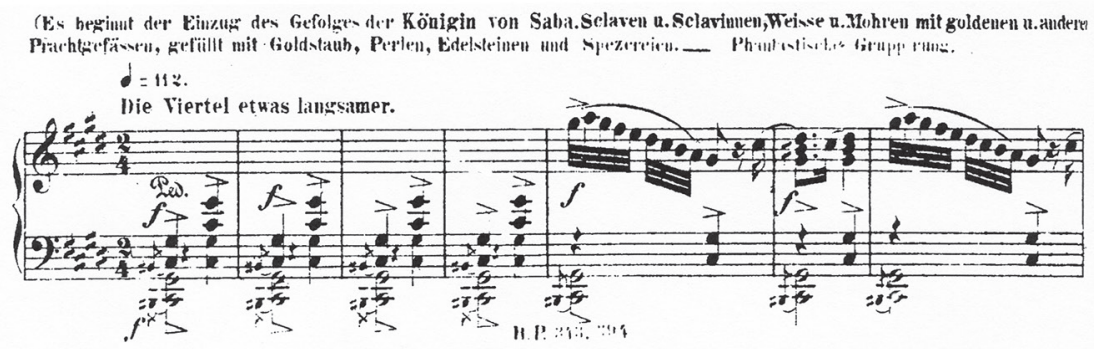


Example 6D Königin von Saba, Einzugsmarsch, "Weisse und schwarze Sclavinnen”

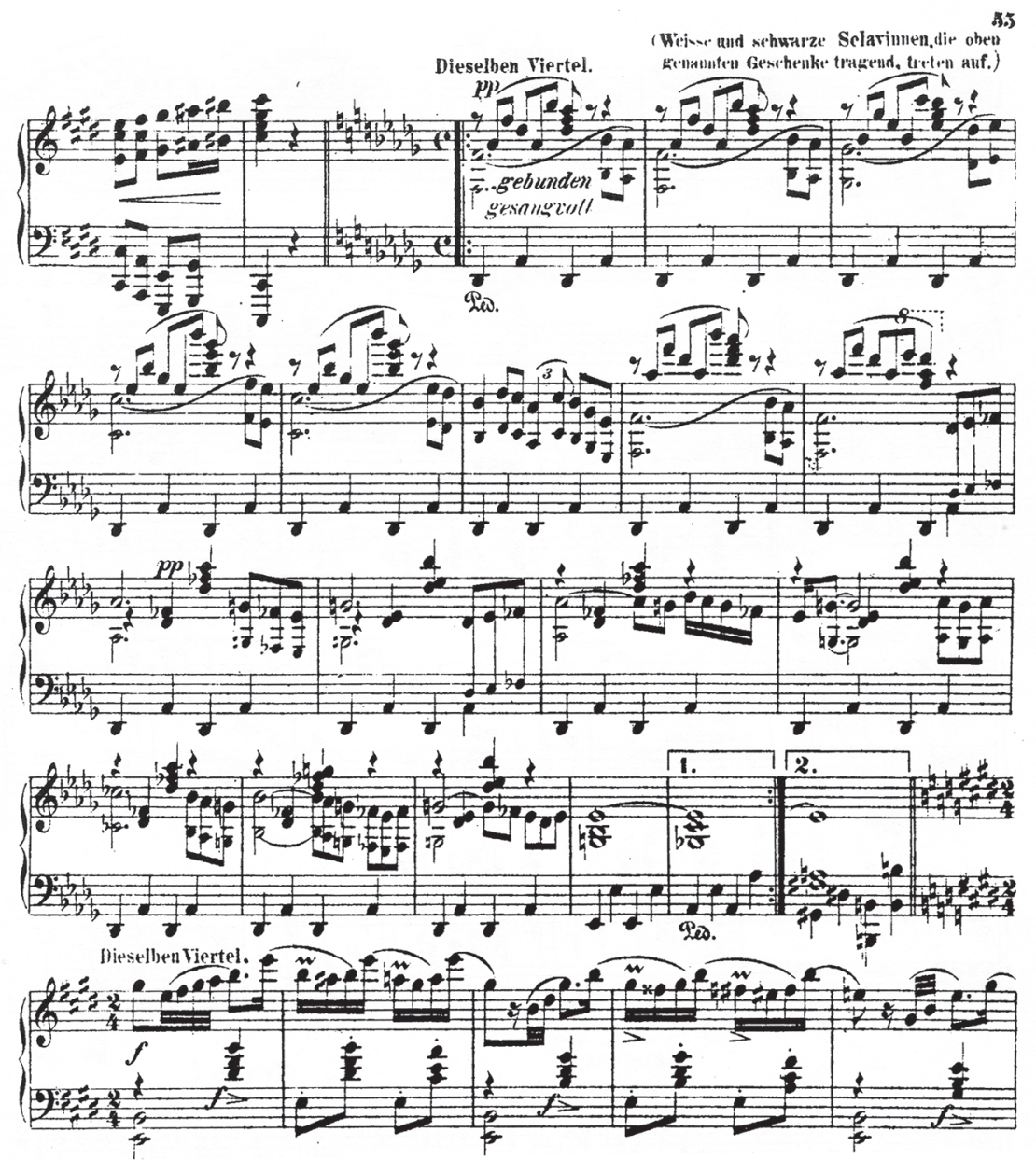

"them." Is it then just an all-purpose Orientalizing marker, functioning at its most utilitarian to conjure up what I sometimes call the generalized harem style? Perhaps not. If on its first hearing we cannot even be sure that it ought to count it as a marker, it is not only because of the "leitmotif problem" (or because, as Aristotle was supposedly the first to say, "one swallow does not a summer make"), but also because the augmented second in Example $7 \mathrm{~b}$ is the mildest, least-marked form an augmented second can take in normal harmonic usage. It occurs between the sixth and seventh degrees of the harmonic minor scale, a scale good little Aryan boys and girls practice on the piano every day. Its recurrence in the Temple scene does make it a marker, right enough, but it seems to be chiefly serving a preventive purpose, the one Goldmark had in mind when, as he wrote, he "wanted the 
Example 7A Königin von Saba, Prelude, mm. 17-20

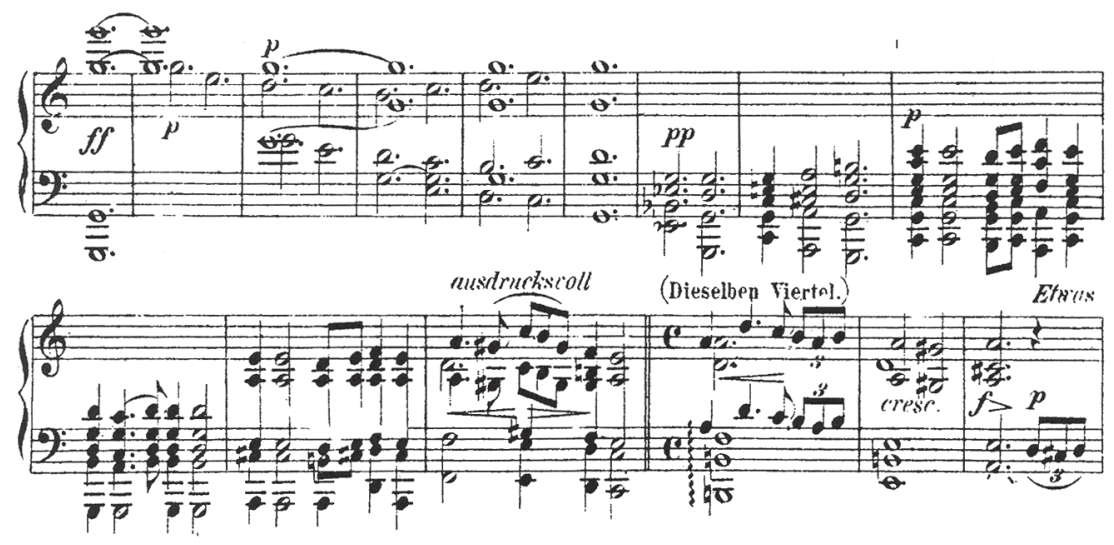

EXAMPLE 7в Königin von Saba, Act II, "Chor des Volkes"

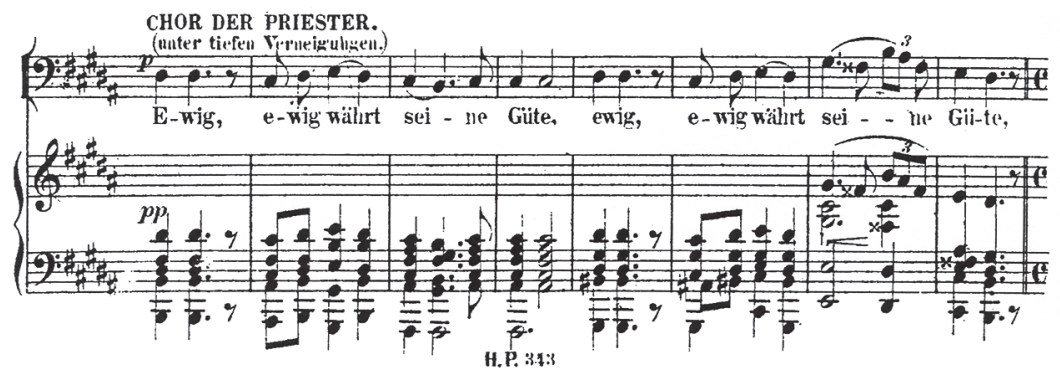

temple hymns [...] to express a sense of consecration and religious feeling [...] without making use of the Protestant chorale or any of the Catholic hymns to the Virgin." Thus the Hebrews get the weakest, blandest, most minimally marked of all possible oriental tinges.

The augmented seconds associated with the Moorish slaves in the Queen's retinue were, by contrast, of a kind that could never occur in normal - that is, unmarked - nineteenth-century European harmony. They occur between the third and fourth degrees, as in the so-called Gypsy scale, or (more euphemistically) the Hungarian minor. They are literally outlandish, in the now somewhat archaic, etymological sense, along with what at least one critic, Richard Specht, called the Goldmarktriole, the Goldmark triplets, which according to Specht marked Goldmark's alttestamentarisches, trunkenes Gepräge, his "Old-Testament, drunken character," even though his use of the device actually went back to Sakuntala. ${ }^{28}$

28. Richard Specht, "Karl Goldmark, zu seinem hundertsten Geburtstag," Pester Lloyd (1930), http:// www.pesterlloyd.net/html/1930spechtgoldmark100.html. 
More outlandish yet is the so-called Lockruf, the weird melody Astaroth is given to sing in the second act of Die Königin von Saba as a prelude to the love scene - a truly bizarre moment. Astaroth tells the Queen that Assad is lurking in the vicinity. The Queen gives her an order: Tiefe Stille rings umher - Niemand sieht uns - lock ihn her! ("Deep silence all around - no one sees us - lure him hither!") Whereupon Astaroth sings an incantation, brilliantly recorded in 1925 by Selma Kurz (1874-1933), the reigning coloratura soprano of the Vienna Opera since Mahler's day, which Richard Strauss surely remembered when composing Salome (you can hear her still, unbelievable trill and all, via YouTube at https:// www.youtube.com/watch?v=wcpdM_N1HxQ). This is the text, by Mosenthal:

Wie im Schilfe lockt der Reiher,

Wie der Tauber girrt im Moos,

Durch der Nacht verschwiegnes Schleier

Lock ich ihn in deinen Schooss.
As reeds attract herons,

As doves coo in the moss,

Through the night's concealing veil

I lure him to thy lap.

These verses are all about locken (luring), so calling the piece a Lockruf makes perfect sense. In the Goldmark literature, such as it is in English, the word is usually translated as "siren song," but its more usual, zoological, meaning is "mating call," including the kind that hunters simulate with a specially designed instrument - Lockmittel or Lockpfeife - to lure their quarry, which is just what the Queen of Sheba is doing here, with Astaroth as her instrument. What Astaroth

EXAMPLE 8 Königin von Saba, Act II, Astaroth's “Lockruf”

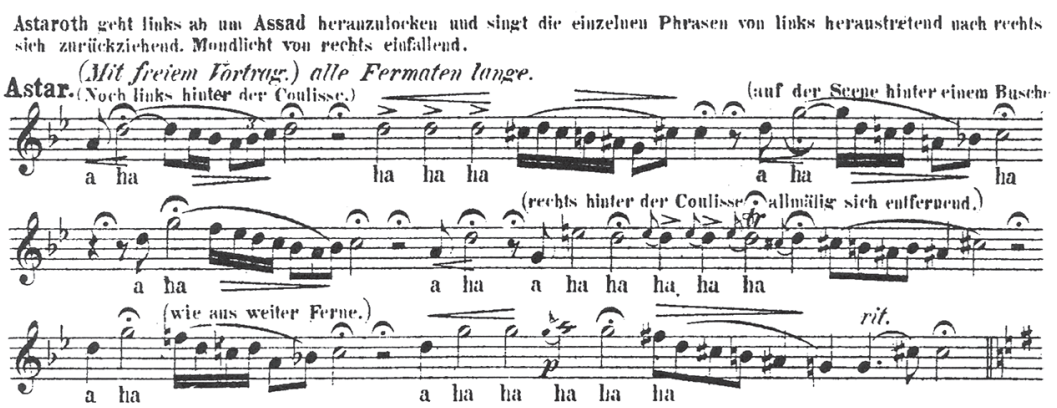

is singing, then, amounts to a sort of duck call (or, if you remember what Assad means in Arabic, a lion call), and sure enough, in wanders the lion, ensnared, singing the most famous item in the whole opera. We will get to that in a moment, but first let us take a closer look at the Lockruf as a melody (Example 8).

This is a tune that cannot be referred to any known scale - that is, any single scale. It is a sort of composing-out of the Salome-like progression at the beginning 
of its orchestral introduction, in which a G-minor scale alternates with one based on the diminished-seventh chord containing G. Its modality is thus unstable, but its heavy infusion of weird intervals - the augmented seconds paling next to the cadential tritones - leaves no doubt as to its status. As an orientalist marker, it belongs to a very particular class: the kind I wrote about at length when describing the erotic orientalism of Russian operas such as Ruslan and Lyudmila or Prince Igor - or Rubinstein's Demon, to pick an opera that Goldmark is very likely to have known number by number. ${ }^{29}$ And noting this parallel is a reminder how deci-

EXAMPLE 9 Königin von Saba, Act II, Anathema Scene

("Posaunen auf dem Theater hinter der Scene")

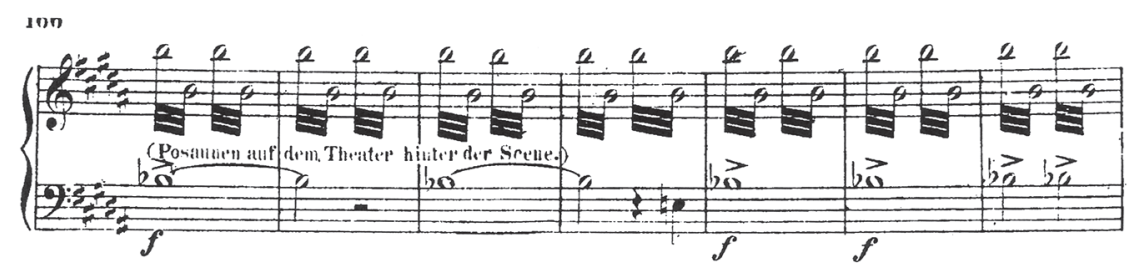

sively our reading of any signifier depends on context - specifically, it reminds us that signifiers generally come in clusters. The cluster tritone-plus-soprano-voice equals "Lockruf," but a tritone blared out by a team of trombones in unison under a dissonant suspension in the same opera signifies "Anathema" (Example 9).

Thus tone color and dynamics, though seldom given as much notice as pitch and rhythm, play no less critical a role in marking and signification - and this applies as much to voices as to instruments. The most famous item in Die Königin von Saba, the promised item we have been postponing, furnishes vivid proof. One of the signal points to emerge from an examination of Russian orientalist markers was that the orientalizing tropes favored by Glinka, Borodin and Rubinstein tropes I associate with the Russian word nega, which means the sweet lassitude of love - had the effect of emasculating the men lured. This certainly applies to the number that the Lockruf calls forth from Assad in Die Königin von Saba - a romance called "Magische Töne," which was recorded time and again by all of the world's most famous tenors when the opera was a repertory item, everyone from Leo Slezak, who was particularly famous in the role of Assad, to Enrico Caruso. But among the treasures now miraculously accessible on YouTube is a recording made in 1903, early enough for Goldmark to have heard it, by the Hungarian tenor Dezső (Desider) Arányi (1868-1923), which exquisitely realizes the demands of the number's ending, which goes way up into falsetto tones that were increasingly

29. See R. Taruskin, “'Entoiling the Falconet:' Russian Musical Orientalism in Context,” in Defining Russia Musically (Princeton: Princeton University Press, 1997), 152-185. 
Example 10 Königin von Saba, Act II, “Magische Töne,” end

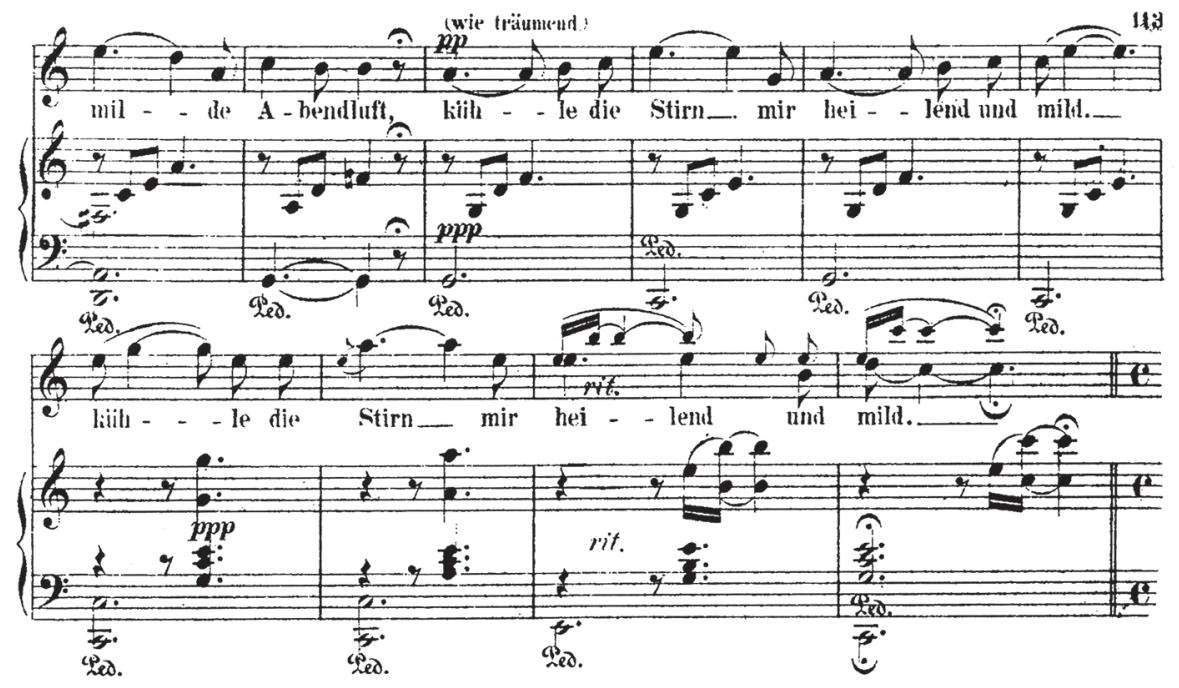

foreign to the technique of twentieth-century tenori robusti like Caruso, as Goldmark acknowledged with an ossia. If at all possible, one should compare Example 10 with https://www.youtube.com/watch?v=cXshaykDq8o.

That eunuch sound, an echo of the old musico or alto travesti, was another potent orientalist marker. Assad at this moment is closely akin to Glinka's Ratmir in Ruslan and Lyudmila, a part cast for a contralto in trousers. Various characteristic instrumental timbres were equally evocative of the East, the cor anglais most predictably, to the point of being hackneyed; and Goldmark gives it plenty of work to do, especially in Act IV, when the Queen is making her final desperate appeal to Assad. Any Biblical opera will have a lot of harp as well, both in the pit and probably on stage; and here, too, Goldmark does his bit. But almost as commonplace was the use of "Turkish" percussion, an old Vienna specialty going back to the eighteenth century. It, too, is often to be found onstage as well as in the pit, and its moment comes in Die Königin von Saba when Sulamith's maiden friends, forming themselves into a backup chorus, accompany her confident paean to her betrothed in the first act ("Der Freund ist dein"). The stage directions call for them to play harps, tambourines and triangles. The harp parts are played in the pit and mimed on stage, but the tambourines and triangles are actually meant to be played by choristers, and their parts are printed, most unusually, in the vocal score (Example 11). You can hear them clearly even in old recordings of the number, such as the one featuring Mária Németh, another Vienna coloratura star, accessible at https://www.youtube.com/watch?v=wLPI6xhX0M8. Although there 
have been fairly recent and complete recordings of Die Königin von Saba, and though the performances they preserve are creditable enough, century-old recordings remain indispensable for the simple reason that one hundred years ago the world's best singers were singing Goldmark, which they no longer do, and their habits of voice production reinforce the semiotic point of the present discussion in ways that more recent singing might easily impede.

Sulamith's roulades in this her signature number could be likened to arabesques; but without the rest of the signifying cluster, which is to say the accompanying percussion, there would be no reason to think her characterization orientalist. The tonality is straightforward $\mathrm{F}$ major, alternating in the middle section with the flat mediant, a voluptuous effect that Viennese audiences had been enjoying since the time of Schubert. It is the unusual 6/4 rhythm, with its longheld syncopations, that seems most clearly calculated to convey the specifically

Example 11 Königin von Saba, Act I, "Der Freund ist dein"

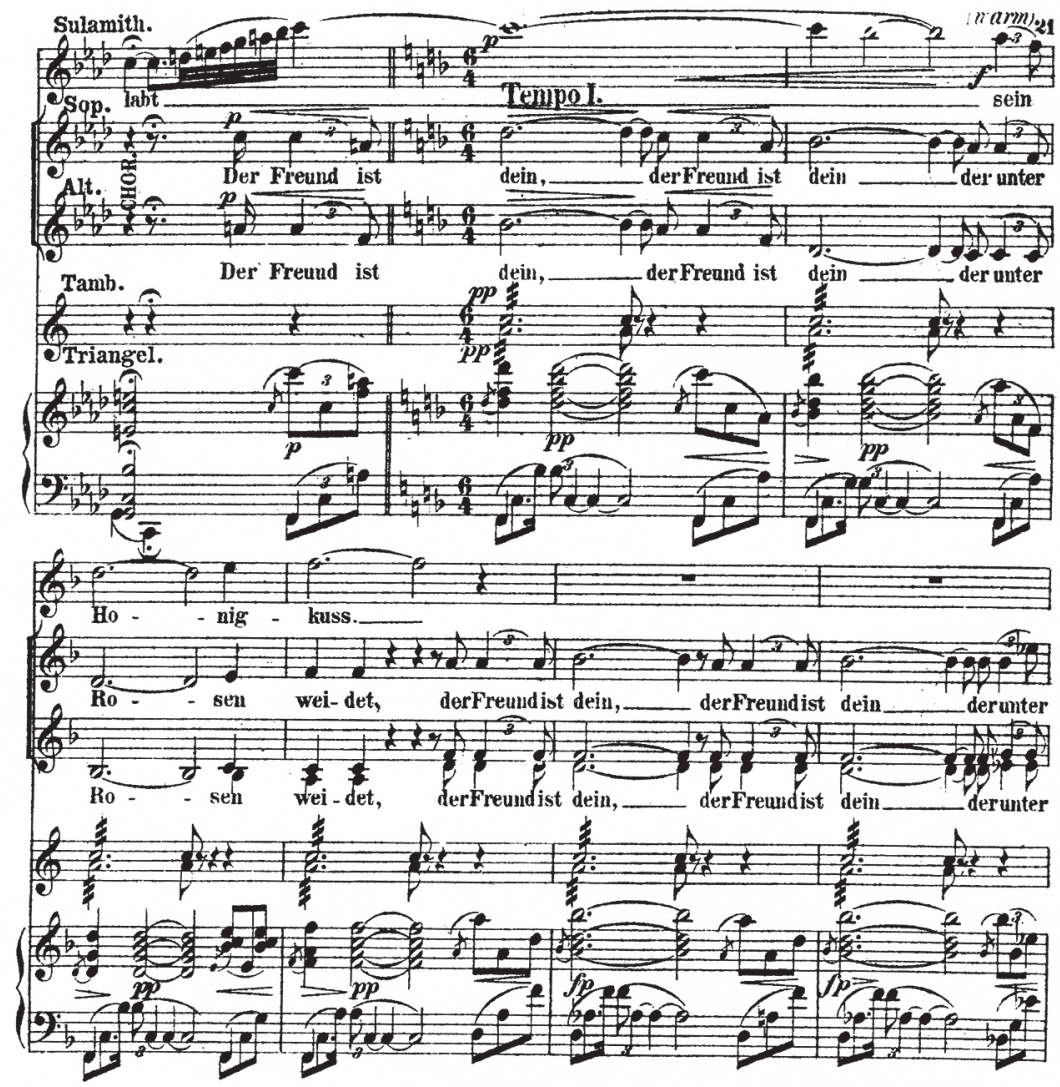


oriental, luxuriant, languid quality associated in Russian operas with nega. The number is reprised at the very end of the opera to accompany Assad's death in Sulamith's arms. The presence of the backup chorus in the wilderness is an improbability that Goldmark was evidently willing to risk for the sake of the poignant musical reminiscence; but the accompanying percussion, along with the harps, are assigned this time not to the terrestrial maidens but to cherubs, who appear, instruments in hand, in the clouds.

\section{4.}

The two characters in the opera least marked with orientalizing tropes are King Solomon, whose role appears to have been modeled on that of Sarastro in Die Zauberföte, and, perhaps surprisingly, the title character. Solomon, if he is orientalized at all, is orientalized merely by virtue of a harp-heavy accompaniment when he is being particularly wise (as for example at the end of Act III, when he commutes Assad's death sentence). As for the Arabian Queen, consider the beginning of the second act, the act that will shortly present the opera's most blatant orientalisms, including the Lockruf. It opens with a long solo scena, an internal monologue in which the Queen reveals that, although she had refused to acknowledge Assad in the preceding act, thus precipitating the tragic action, she nonetheless fully reciprocates his passion.

Her music is full of signifiers, but none is in any way fremdartig. Rather, they betoken agitated emotion, the primordial operatic stock-in-trade in which all human nature is assumed to be one. Alone and unobserved, the Queen is stripped bare and exposes her soul, which, being human, exemplifies not any particular subgroup to which she happens to belong (women, queens, Arabs), but only her which is to say us. To be unobserved, in other words, is to be unmarked. A character alone onstage is in no need of differentiation from others, and is consequently to be portrayed as simply - that is, universally - human. Feelings expressed by a soliloquizing soloist belong to everyone. To represent them is to stress commonality with the observer beyond the fourth wall, unportrayed but tacitly acknowledged.

Corroborating examples come readily to mind. The second act of Borodin's Prince Igor is a riot of oriental color from start to finish, except for the central moment: Igor's soliloquy in which, alone on stage, he sings of his longing for freedom, a moment devoid not only of oriental coloration (which we would not expect of him in any case) but of Russian coloration as well (which we might indeed have expected were we operatic novices). By contrast, the strophic song sung in the first act by Igor's brother-in-law, Prince Galitzky, being what film scholars call a diegetic number (or, to use Carolyn Abbate's language, a "phenomenal" song), 
performed in the presence of others, is for both of these reasons marked "Russian" by the use of stereotypical folkloric turns of phrase (specifically the cadential progression 5-4-1). Another example, perhaps the best known of all: when in the presence of Don José, Carmen expresses herself in habaneras and seguidillas, but when alone onstage (turning cards, for instance), she sounds like Bizet the way the Queen of Sheba alone on stage sounds like Goldmark.

There is a theoretical side to this, usually tacit, but evidently well enough known to composers of nineteenth-century operas, whether nationalist or exoticist (two sides, after all, of a single coin). The most explicit enunciation I know comes from César Cui's review of Rimsky-Korsakov's first opera, Pskovityanka (The Maid of Pskov, 1873). Rimsky had set a love duet for the title character and her star-crossed lover to the tune of a Russian folk song he had found in a published anthology. That, announced Cui (both a paid reviewer and composer's elder brother kuchkist) was a tyro's mistake:

One can give a folk song to a chorus representing the folk; one can give it also to individuals who are singing a song; but individual feelings cannot be poured forth in the sounds of a folk song. Here Olga and Tucha are speaking of their own love, of their own feelings; in such a spot the sounds of a folk song are altogether out of place on their lips. ${ }^{30}$

The rule Cui here invokes applied to other-making markers and self-asserting ones alike. Goldmark never stated it as a rule, the way Cui did; but he surely followed it in practice - and in a particularly subtle, self-aware fashion that bespeaks high consciousness of it. His Queen when unobserved is unmarked; but as soon as she is observed, she immediately sprouts exoticist markers. Consider the narrative in which Assad describes to King Solomon his first encounter with the Queen, unclothed and therefore unidentified, but full of sexual allure. After the verses that were often recorded by Leo Slezak and others - evoking the cedars of Lebanon, the plashing of a silvery brook, and so forth - comes the fatally seductive vision.

Goldmark's musical marker of sexual allure had occurred first in the Prelude (Example 12). My Stravinsky-educated ears certainly pricked up when I heard the sudden excursion into Wagner by way of Liszt. It carried me back to my early investigations, three decades ago and more, into the sources of Stravinsky's harmonic practices. Goldmark's chromatic sequence goes through two progressions encompassing three out of the four members of a circle of minor thirds, and the bass, which links the roots of the chords in the progression with passing tones, performs a complete octatonic scale, to give it a name Goldmark would never 
have used since it was not coined until $1963 .{ }^{31}$ But that tone-semitone scale, when juxtaposed with diatonic harmony, had been a marker of apartness (supernatural, exotic, sublime) since the late 1840s, when Liszt (having observed it in Schubert) made it one of the main constituents of his first symphonic poem, the so-called Mountain Symphony, and a whole school of Russian composers, having educed it from Liszt, made it their symbol par excellence of the uncanny. ${ }^{32}$

Goldmark's usage is not systematized the Russian way, and he never takes the circle of thirds through the full fourfold progression to completion, which suggests that he did not have an a priori conception of his bass line as a scale or mode. On its many further appearances in the opera, which consistently identify it with the passionately erotic, illicit liaison between the Queen and Assad, the motif goes through only two sequential progressions. But its preliminary appearance in the

EXAmple 12 Königin von Saba, Prelude, mm. 24-35
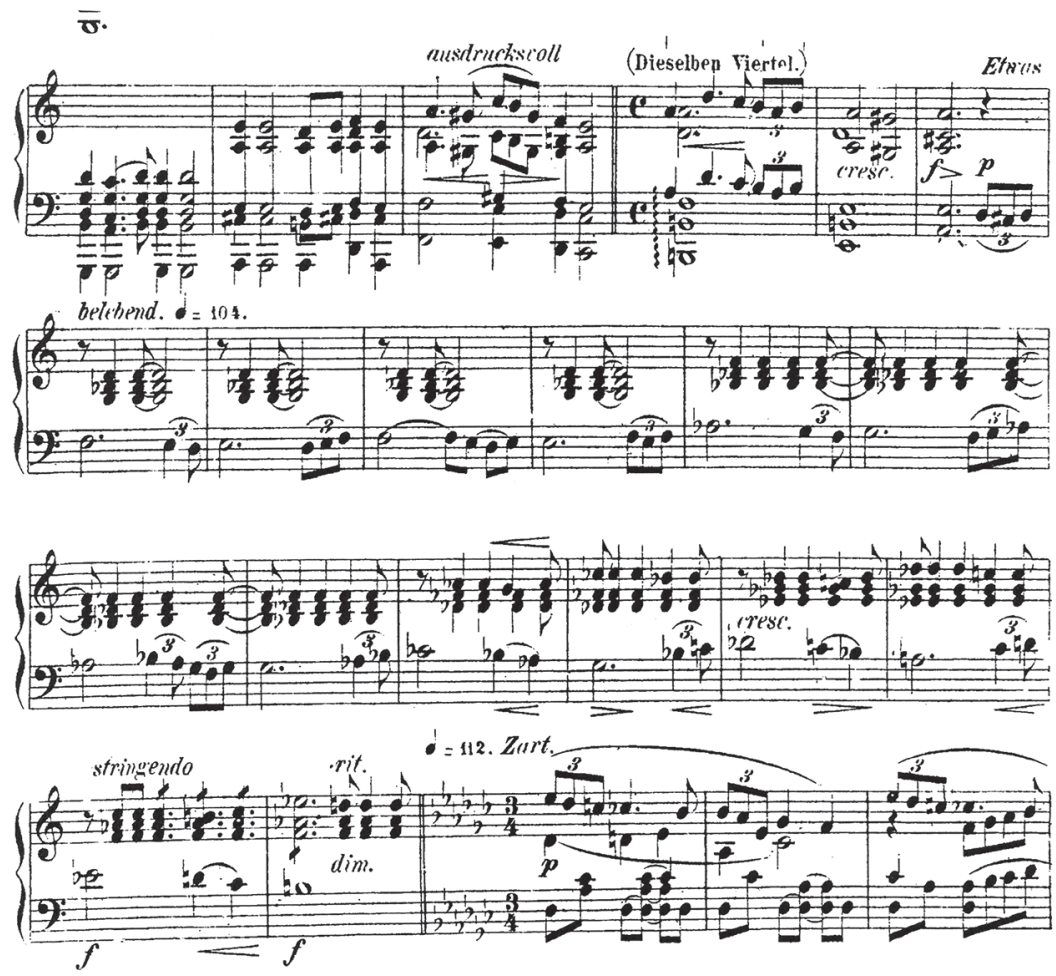

31. By Arthur Berger in "Problems of Pitch Organization in Stravinsky," Perspectives of New Music 2/1 (1963), 11-42.

32. For the history, see Richard Taruskin, "Chernomor to Kashchei: Harmonic Sorcery; or, Stravinsky's 'Angle,"' Journal of the American Musicological Society 38 (1985), 72-142. 
Prelude, in a fuller form, makes it instantly recognizable as a leitmotif as it gains context and thus specificity of reference. In its further appearances, including Assad's confessional narrative, it is often placed in conjunction with Goldmarktriole and augmented seconds, producing a signifying cluster that associates the Queen (when observed) both with sex and with the inscrutable East. Its appearance in Assad's narrative is heralded, in fact, by a fleeting preliminary reference to the music that will accompany the black slave girls when they appear, in the opera's next scene, as part of the Queen's retinue (Example 13).

This is an exceptionally subtle and canny deployment of markers. When delivering his narrative to Solomon, Assad does not yet know that he has seen the Queen of Sheba. All he knows is that he has seen a sexy alien body. And so at this point the augmented seconds signify exactly what they will signify during the Queen's procession in the next scene. But once he has witnessed the Queen's official entrance and - to his horror - recognized hers as the sexy body he had previously encountered, she takes on another identity, and with it, another set of signifiers. Similarly, the proto-octatonic motif that signifies the mutual passion kindled in Assad and the Queen haunts each of them when thinking of the other:

EXAmple 13 Königin von Saba, Act I, Assad's Narrative

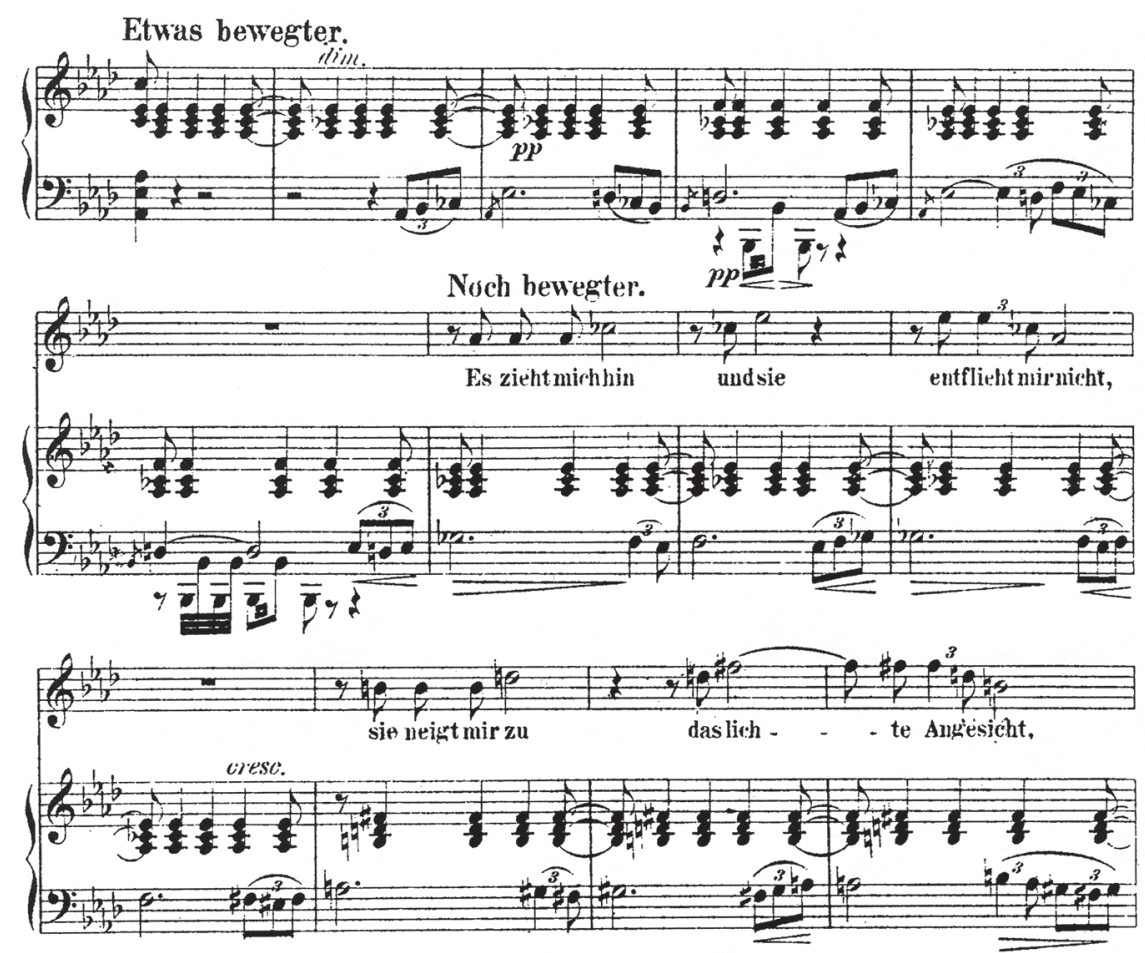


it signifies them in each other's eyes as sexually objectified rather than as sentient subjects.

Of course I am using language that would never have occurred to Goldmark. But regardless of the language used to describe them, the composer is making remarkably fine discriminations and distinctions through the use of orientalist markers. He differentiates his characters by gender, race and social class (again using our language for categories to which he might have given other names), and also according to the angle of surveillance - that is, whether a character is being observed only by the audience, or by other characters with their own points of view. Goldmark's markers convey a wealth of meaning above and beyond the rough breakdown into four categories (Israelite at court and at worship, Arabian and Moorish) to which he proudly but quite inadequately called attention in his memoirs. We have seen them all in action and interaction in the characterization of the Queen, of Astaroth, of Assad, of Sulamith and of King Solomon, as well as the chorus and the corps de ballet as variously costumed.

But we have seen much more than that. In redeeming his boast, Goldmark showed himself to be the consummate eclectic: a master of a thousand styles, which he could deploy in myriad combinations according to a consummately expert and rationalized technique. In saying this - and obviously I am saying it in admiration - I am well aware that I am describing Goldmark exactly the way Wagner described Jewish musicians in order to denigrate and discredit them. To which Wagner would say: What would you expect from a Jewish musicologist? To which I say: Goldmark's superbly rationalized modus operandi is the modus operandi of all skillful composers, certainly not excluding Wagner, whose mature musical technique - or musical style, which in his case amounted to almost the same thing - was perhaps the most thoroughly willed and rationally contrived in the whole history of European music.

It is only Wagner's incredible success as a propagandist, repackaging and re-energizing a lot of romantic claptrap that still holds too many of us in thrall, which keeps us now from seeing Wagner the way Wagner saw Mendelssohn and Meyerbeer. Karl Goldmark can help us get over him. 